\title{
A legal geography perspective on protected areas : lessons learnt from Table Mountain National Park (Cape Town, South Africa)
}

Géographie du droit et aires protégées : Expérience du parc National de la Montagne de la Table (Le Cap, Afrique du Sud)

\section{Nadia Belaidi}

\section{OpenEdition}

\section{Journals}

\section{Electronic version}

URL: http://journals.openedition.org/rge/7997

ISSN: $2108-6478$

Publisher

Association des géographes de l'Est

\section{Electronic reference}

Nadia Belaidi, «A legal geography perspective on protected areas : lessons learnt from Table

Mountain National Park (Cape Town, South Africa) », Revue Géographique de l'Est [Online], vol. 58 / 1-2 | 2018, Online since 19 April 2019, connection on 08 September 2020. URL : http:// journals.openedition.org/rge/7997

This text was automatically generated on 8 September 2020

Tous droits réservés 


\title{
A legal geography perspective on protected areas : lessons learnt from Table Mountain National Park (Cape Town, South Africa)
}

\author{
Géographie du droit et aires protégées : Expérience du parc National de la \\ Montagne de la Table (Le Cap, Afrique du Sud)
}

Nadia Belaidi

Law is constitutive of social relations and relational identities (wife, owner, citizen...), of the institutional world within which we act (the nation state, the community, the firm, the market, the family...) It can be understood as constitutive of social reality (Blomley, Delaney, Ford, 2001: preface). Each of these domains is what it is due to its legal definition. Law as an instrument of change, domination or resistance, and as a means through which justice might be given practical realization, has, in innumerable ways, shaped - however provisionally - the basic terms and experience of social life. As law might be seen as a constitutive of the social realm, legal matters obviously play a profoundly influential role in how human-environment interactions are carried out. It is through the complex mass of directives, doctrines and institutions associated with environmental regulation and management - the latter being already complex and open to a range of interpretations and assessments - that law deals with the "humanenvironment interactions". Law and space, then, have everything to do with nature both as a rhetorical figure and a physical reality. In this framework, the approach of legal geography (Blomley, 1989, 1994 ; Urban Geography, 1990a, 1990b ; Delaney, 1993 ; Blomley et al., 2001; Holder et Harrison, 2003 ; Thom, 2004 ; Taylor, 2006 ; Forest, 2009 ; Braverman, 2011 ; Braverman et al., 2014), by seizing the spatial context of legal phenomena, questions the role of law in the reproduction of social relationships and the support of geography for the construction of legal standards (Belaidi et Koubi, 2015). Further as social history of the Table Mountain in South Africa depicts its symbolic role in the relation to the city (Goetze, 2002 ; Fuller 1999), the creation of the 
Table Mountain National Park (TMNP) in 1998 offers a good case study for this approach. on the various conflicting issues which would deter us from the specific focus of this paper ${ }^{1}$.

3 A White Group Area since 1957(until 1990²), TMNP is located entirely within the boundaries of the City of Cape Town and its specificity lies in its location in peri-urban area, isolated from other natural landscapes. It has undergone a considerable touristic pressure (4 million visitors a year, SANParks, $2016: 20$ ) and is surrounded by discriminated black communities. This last point has meant that SANPark (South African National Parks), the National Park Authorities, have set up a service of social ecology thus making the park an active and voluntary tool of social integration of these discriminated communities. We can therefore acknowledge the challenge underpinning the geographical location of Table Mountain National Park at the outskirts of Cape Town, its part played in the tourist industry as well as in the protection of a world heritage environment.

4 As the TMNP is clearly separated from the urban areas of Cape Town, there is a real frontier between the two spaces : the protected area on one hand and the urban settlement on the other hand (fig. 1). However, if this area can easily be considered a "frontier space" (Hohl, Tisdell, 1994 ; Griffiths, Robin, 1997 ; Dovers, Edgecombe, Guest, 2002), it does not coincide with "historical frontiers" nor with geographical definitions. So, this space constitutes a "new generation of frontiers" (Guyot, 2009) and it takes place within the current context in which ecology and sustainable development play a central role. That is to say that the term "frontier" is meaningful. It signifies, it differentiates, it unifies the inner spaces that it determines. Its definition refers to constellations of social relational powers. The shape that this meaning often takes - the meaning that social actors confer to lines and space - constitutes a legal meaning. Its significance is materialized by the authoritative inscription of legal categories, or the projection of legal images and stories onto the material world of things (Blomley, Delaney, Ford, 2001). As TMNP is a strategic space in regard to the future of the city, biodiversity and tourism, this "ecologically-based" area is a social tool. It is precisely the process that we are questioning : how is TMNP used? what for ? As authorities make the environmental protection and the protected areas play a role in the development of the city of Cape Town in the long-term, law can help determine this role. $^{3}$ 
Figure 1. Cape Town metropolitan area : urbanisation and protected area

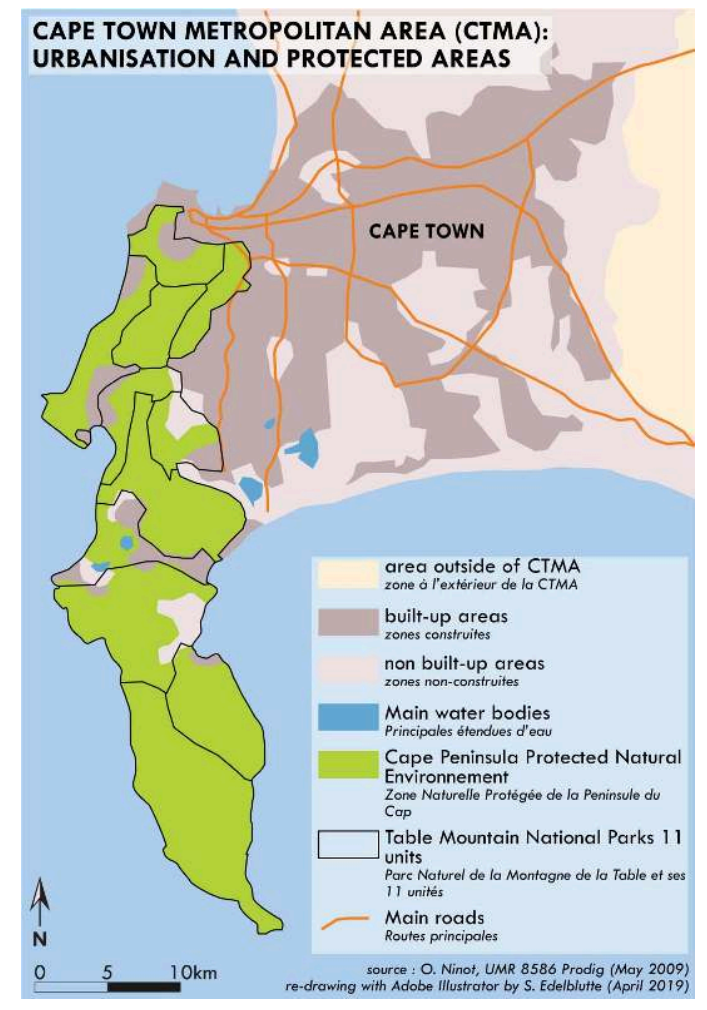

O. Ninot, UMR 8586 Prodig (May 2009)

5 Taking legal themes such as the connection between law as discourse or representational system and law as power instrument seriously opens up a variety of questions about how - through what kind of practices, in relation to what social or political projects - social space is produced, maintained or transformed (Blomley, Delaney, Ford, 2001). Despite these characteristics, little critical attention has been paid to law merely considered as other black-letter rules and regulations. There has been, in the last thirty-five years, an explosion of environmental law studies because of the recognition of the often-controlling role of law in shaping human environments. Perhaps because it is largely policy oriented, the vast and heterogeneous literature approach to environmental law tends to be instrumentally normative more often than epistemologically critical. Despite the interesting work being done by environmental legal scholars and since it tends towards a realistic conceptualization of nature, it does not raise questions about discursive construction of nature.

We therefore suggest here to use a legal theory and category not for its "legal power" but for its heuristic capacity. We intend to use the French legal theory about la destination de la chose $e^{4}$. This theory doesn't exist in common law. Since "la destination" is a human creation turned into the achievement of a purpose (see especially Boffa, 2008 : 4), we shall use the term purpose of the thing to deal with this French theory. This purpose is the action performed by someone (individual, institution ...) on something : it is its expression of will on a specific thing. This notion, as it refers to the use made of a thing, doesn't only depict the function attributed to the thing; it also applies to the permanent result towards which the use of the thing has to tend. That is to say that the affectation (the function attributed to the thing) is an act of willpower : the act by which a thing is subjected to a definite use and the purpose refers to the sustainable and 
permanent aim of the thing. The affectation is a constituent of the emergence of the purpose : it expresses what is. The purpose expresses what has to be. So when a person chooses a purpose for something, this action prints a trajectory in the thing which does not depends on the nature (the own character) of the thing. The aim of the purpose is expressed in the "law" upon which the thing will be operated. So the purpose brings a thing in a regime (set of rules that could be applied to a thing) differing from its origin - based on its nature, and disconnects the nature/regime relationship.

7 As this French legal theory is focusing on the specific function that can be attributed to a thing, it underlines the idea that a thing with only one nature could have other purposes, thus other regimes, possibly different from its intrinsic nature. As it suggests a definition based on the nature of a thing - which can be a natural space - on one hand, and what is really done of this thing, on the other hand, this theory is a good tool to discuss the social use of TMNP.

8 One of the major motivations in creating the TMNP is to constitute the proper area to protect efficiently biodiversity, the TMNP seems to be a project that conquers wilderness ${ }^{5}$ in order to preserve biodiversity ${ }^{6}$. Its own characters - here biological and physical - are the object of the law. Although the aims of preserving wilderness and conserving biodiversity differ (Sarkar 1999), the tasks of biodiversity conservation and wilderness preservation converge (Graber 1995). On one hand, they share one type of targeted habitat : fragile ecosystems or those with rare or endangered species. On the other hand, many issues of concern for wilderness protection are equally important to the conservation of biodiversity. These issues include at least four anthropogenic factors - unbridled market forces, overconsumption, human encroachment, invasive technologies - that contribute to the extinction of populations, species, and ecosystems. We thus deal with a space with biological and physical fundamental services. Based on this nature, its (intrinsic) function is to maintain biodiversity and life support system. In order to rule that function, the intention of SANParks is to incorporate all the landholdings, public and private, into a single national park : Table Mountain National Park (TMNP). This land consolidation constitutes therefore a determined strategy on behalf of SANParks. But if the major function of the TMNP is only to preserve and minimize the impact on biodiversity, this authority could stop here and promote tools in order to preserve biological and ecological processes. Yet it adds another function to this park, namely its social dimension. At the same time and with the same project, South-African Authorities are looking for something else than the mere protection of biodiversity. They are looking for another purpose for this protected area : biodiversity might support social ecology. The management of the Table Mountain National Park has another function than protecting biodiversity and recreation : it is transforming this space into another, from a protected area to a postapartheid area $^{7}$. This point is important because social interests, whether those of social justice movements or aspirations for economic improvement, could be critical to conservation efforts. Here, the French legal theory about la destination de la chose helps to qualify the strategy on this protected area. Through the reading of the social values of law it enables, the theory can help interpreting the space according to its social significance and, thus, could question what Table Mountain National Park has become. 


\section{Table Mountain National Park : A protected area}

\section{(1)}

highest in the world. It is the pre-eminent area of the world's five Mediterranean climate regions which in total account for $2 \%$ of the earth's land area yet $16 \%$ of the world's plant species. The floral diversity compares favorably with that found in some areas of the neotropical forests. The CFR has much higher levels of plant diversity and levels of endemism than other Mediterranean-type climate regions ${ }^{8}$. That is why the CFR has been called the world's 'hottest hot-spot' for plant diversity and endemism and has been designated as one of the IUCN World Centres of Plant Diversity. Although it is the smallest of the world's six main floristic regions, the CFR includes five endemic families while the whole of southern Africa hosts a total of 12 endemic families. It has a high level of dependency, with almost 6,000 of the 8,500 plant species which are endemic to the region. In less than $0.5 \%$ of the area of Africa it has nearly $20 \%$ of its flora and in less than $4 \%$ of the area of southern Africa it has nearly $44 \%$ of the subcontinental flora of 20,367 species. Nearly $69 \%$ of its vascular plant species do not occur naturally anywhere else in the world. Within its $90,000 \mathrm{~km}^{2}$ area there are 8,996 plant species and 988 genera, roughly half of all genera in South Africa. These include 1,435 (70 \%) of all southern African threatened species. (Government of the Republic of South Africa Department of Environmental Affairs and Tourism 2003)

11 It is in recognition to these levels of biodiversity and endemism that the Cape Floral Region has been designated as World Heritage site under natural criteria (ii) and (iv). Following the Criterion (ii) - ecological processes, the Cape Floral Region is considered of outstanding universal value for representing ongoing ecological and biological processes associated with the evolution of the unique Fynbos biome. With the Criterion (iv) - Biodiversity and Threatened Species, the Cape Floral Region is recognized as one of the richest areas for plants than any similar sized area in the world (World Heritage Nomination - IUCN Technical Evaluation, 2004). This inscription means that this space carries common values for the whole of mankind (see Kiss, Beurrier, $2000: 236-240$ ). The Convention Concerning the Protection of the World Cultural and Natural Heritage (Paris, November $16^{\text {th }}, 1972$ ) highlights the idea that some sites under States sovereignty have an interest which exceeds the borders of the territorial States and concern the all mankind. Here this interest lies in its ecological functions.

These processes are generally represented within the Cape Floral Region (CFR) and captured in the 13 nominated clusters that make up the CFR. So the TMNP, as it included the Cape Peninsula National Park (CPNP) nominated as cluster of the CFR with its 4,651 plant species and a level of endemism of $31.9 \%$, has a plant biodiversity unparalleled in other temperate biodiversity "hotspots" and compares favorably with other sites either on or proposed for the World Heritage List for their botanical values. This pattern of wealth of species is exceptional for this climatic type. But the latest estimates indicate that $6 \%$ of all the plant species on the Peninsula are threatened, which emphasizes the urge for International recognition and conservation of this area.

Revue Géographique de l'Est, vol. 58 / 1-2 | 2018 
13 Furthermore, since 1998 only the Cape Peninsula National Park (CPNP) is under special protection. But if the CPNP can ensure the sustainable conservation of most of this exceptional biodiversity, it is only because it is buffered by the remaining portions of the Cape Peninsula Protected Natural Environment (CPPNE) (Government of the Republic of South Africa Department of Environmental Affairs and Tourism, 2003). Further analyses show that the CPPNE conserves the Cape Peninsula's plants, animals and ecosystems because it is large enough to ensure the maintenance of essential natural processes (Cowling \& al., 1991; Trinder-Smith \& al., 1996a, 1996b).

\section{A conservation of the biodiversity defined by the land consolidation strategy of SANParks}

14 Following article 4 of the Convention Concerning the Protection of the World Cultural and Natural Heritage, South Africa has some obligations : to identify, protect, conserve, develop and transmit heritage to future generations. This article means that the State must adopt a general policy to assign a social function to the heritage. Thus, the State must take measures in order to preserve registered sites on behalf and in the interest of the international community. Here South Africa becomes a trustee : it exercises a mandate in the interest of present and future generations (see Kiss, Beurrier, 2000 : 236-240).

15 In order to fulfill this obligation, SANParks therefore intends to enlarge the Cape Peninsula National Park (CPNP) to the full Cape Peninsula Protected Natural Environment (CPPNE), the only way to protect efficiently the biodiversity with World Heritage status. This is the function of the "new" national park : Table Mountain National Park (TMNP).

16 Following the process initiated in 1996 (see SANParks 2008, SANParks and Settlement Planning Services - Land Use \& Environmental planners, 2001) to consolidate the land holdings within the CPPNE under SANParks authority and proclaim most of the land within the CPPNE a National Park, the first portions of the Cape Peninsula National Park (CPNP) were proclaimed during May 1998. The three major conservation areas the Table Mountain and Silvermine Nature Reserves controlled by the City of Cape Town, and the Cape of Good Hope Nature Reserve under the Western Cape Regional Services - formed the bulk of the CPNP. Ownership of the core protected area of the CPNP lies with the State (State land) and local authorities (public land).

Land within the remainder of the Cape Peninsula Protected Natural Environment (CPPNE) is owned by a variety of public and private landowners. Public land (including the CPNP) forms the largest proportion ( $80 \%$ ) of the CPPNE and is distributed amongst various national, provincial, regional and local authorities. The $20 \%$ of land in private ownership is divided amongst about 174 landowners and includes some private nature reserves. The extent of the core area of the declared CPNP is 17,254 ha. A further 14,480 ha of buffering conservation-oriented land (including State land, public land, private nature reserves and private land declared national park) provides protection to the core protected area, "offering a safe haven to the biodiversity found in this protected area" .

Since its proclamation in 1998, the additional 7,000 account for a total of 23,000 ha, 80 $\%$ of which is consolidated. One significant achievement in the consolidation process was the assignment to it of the Cecilia and Tokai state plantations in 2005, which added 
1,000 ha. The Park currently covers approximately 25,000 ha (SANParks, $2016: 13$ ). The adjoining TMNP Marine Protected Area totals $1,000 \mathrm{~km}^{2}$. The vast bulk of the public land is now in the Park and the main challenge today lies with the remaining privatelyowned land within the conservation area of the CPPNE. It is hoped that all public land will be proclaimed and that the owners of much of the private land within the CPPNE will agree to contract their land into the Table Mountain National Park. The ultimate achievement would consist in the incorporation into the park of the proclaimed 29,000 ha that make up the historic CPPNE.

The Park has put in place a multi-faceted land consolidation strategy. This involves acquiring private land by outright purchase or contracting it into the park through long-term management contracts with land-owners. The Park can offer incentives such as rates rebates, alien vegetation clearing, fire management and other services. Expropriation is a legal option although it has not been used yet. They have also looked at land donations, where they have had some success, but the problem on the Peninsula is the extremely high value of land and some landowners are trying to hold out for development rights. Consolidating all these various public holdings and other conservation-worthy, but privately owned properties into a unified system obviously allows for much more efficient environmental management. Yet, even if SANParks present this land consolidation as a biodiversity conservation strategy (Daitz and Myrdal, 2009 : 332-333), the incentives cannot only be a preservation tool. As an instrument aimed at consolidating the land, it can also achieve other purposes. Indeed, fire management and alien vegetation clearing constitute valid arguments to ensure the protection of the endemic vegetation of the peninsula, thanks to which TMNP owes its status as a World Heritage site preserved from overexploitation and urbanisation. Indeed, fire is critical to the survival of fynbos. Since fires are more frequent than normal, they are expected to have a devastating impact on the species of the Table Mountain National Park. Some shrubs remain vulnerable for a few seasons following a fire, meaning they need time to mature before facing another similar situation. Seed bank may be low and new shoots tender. If a fire sweeps through before they have had a few years of maturity, it could be devastating (Midgley et al., 2005). Several species have already been lost to the Cape Peninsula due to overly frequent fires (Joubert, 2008). Likewise, alien plants are "the greatest proximate threat to floral diversity" (Turpie et al., $2003: 61$ ). Every time alien plants are allowed to spread further across this landscape, they infringe the biological value of the system. Alien vegetation clearing and fire management are good tools protecting bees indigenous to fynbos which remain to be an important contributor to pollination of the fruit industry in the area and mountain fynbos catchment areas to keep on contributing to the regulation of the local water supply (see also Van Wilgen et al, 2001). Indeed, the value of fynbos product harvested for the fresh and dried flower industry, thatching, timber and ferns totalled R78 million per year. Because of the rarity and diversity of the flora, $50 \%$ of international tourists who visit South Africa each year include the Western Cape (and TMNP) in their travels. Many do so in part for the natural environment. Ecotourism, through the passive enjoyment of the area or more active birding, whale-watching and adventure tourism, was estimated to bring R6 406 million to the province annually (Turpie et al., 2003).

21 On top of that, prior to 1998, 14 institutions shared control of public land on the Cape Peninsula. The other major motivation for creating the TMNP was therefore to 
establish a single management authority for the Peninsula. It has been a big challenge because changing authority means changing rules and goals. For example, considering the assignment of the Cecilia and Tokai state plantations to TMNP means managing the exit strategy of the Department of Water Affairs and Forestry from the commercial forestry plantations that were established - right on top of several now critically threatened indigenous vegetation types, and putting in place a management framework for this area allowing the restoration of its natural vegetation. The incorporation of lands into the park is done according to the National Parks Act ${ }^{10}$ which is regulated by SANParks (section(s) 5 of the Act).

\section{Social valuation of a world heritage site}

According to SANParks, Table Mountain National Park (TMNP) must be "A park For All, Forever". This slogan aims at promoting access to the Park for all people whatever their social condition (Daitz and Myrdal, 2009 : 332). In this way, the notion of "reconciliation ecology" (Rosenzweig 2003) is applied to Cape Town. This principle implies to deal with the human injustices associated with the loss of biodiversity or with past attempts to exploit or even protect biodiversity. Indeed, under the apartheid regime, national parks in South Africa were established at the expense of the black South Africans who were driven away from their lands, and were unable to use national parks resources, this principle demands that issues of "inclusivity" and "access" be considered $^{11}$. The former is a fundamental moral responsibility in South Africa to break the legacy of apartheid in the planning process by enabling people from disadvantaged communities to also benefit from natural conservation programmes and protected areas.

Promoted as the heart of the Cape Floral Region, TMNP would be the place where citizens of townships and suburbs can choose to see themselves as part of Nature and thus connect to each other. But even if TMNP is on the doorstep of Cape Town and 70\% of it is freely accessible, many residents still require transport to get there as well as affordable entry. This means that without a social investment, it will not be possible for many people to enjoy the park and feel ownership of this territory.

That's why, in order to make National Parks affordable, SANParks has introduced The TMNP My Green Card, available exclusively to South African residents of Cape Town at the cost of 157 Rands and providing the holder 12 free entries into any of the Table Mountain National Park ticket offices : Cape of Good Hope (Cape Point), Boulders Penguin Colony, Oudekraal and Silvermine, as well as to the braai and picnic areas at Tokai, Newlands and Perdekloof.

25 Furthermore, the Park has obtained support from the government's Expanded Public Works Programme (EPWP) - a national poverty relief scheme.

Today, the Park implements an intensive and co-ordinated alien vegetation clearing program through SANParks Biodiversity Social Projects. The program is undertaken in partnership between the park and Working for Water, a public works EPWP program set up by the Ministry of Water and Forests, which employs between 300 and 350 people from surrounding communities to work in the park. The Park has four sub-projects with annual budgets currently totalling some R24 million per year in 2015 (adjusted annually) (SANParks, 2016: 76). For example, the Milling Project is seen as a ValueAdded industry, the Milling Team specifically mills alien tree species (e.g. gum trees) 
into planks which can be used by SANParks for repairing and building new boardwalks, bird hides, etc. But the most important objective remains the relief of poverty and the development of communities through job creation (sanparks.org).

Already in April 2004, R35 million were channelled through the Department of Environmental Affairs and Tourism's Social Responsibility Directorate for an initial three-year period, and subsequently boosted by a further R6,65 million during a fourth year. Projects included significantly upgrading the existing footpaths, upgrading 22 minor access points to the mountain, erecting directional signage, improving facilities such as picnic sites, building the new tented camps for the Hoerikwaggo Trails and training 60 tourist guides, restoring historic buildings and removing unwanted structures, upgrading some existing "soft" management roads, training 60 visitor safety officers, and employing 10 marine recreational monitors. Participants in the project were selected from previously unemployed residents of six impoverished communities on the borders of the Park and from the Loyola community in Gugulethu, which had been forcibly removed from Simon's Town in the 1960s. In line with government policy, most were women, while the youth and disabled were also well represented. Over the four-year period, a total of 560 people has been employed, spending 24 months on training programmes - like stone masonry - coupled with two years temporary employment. All participants started as general workers on the lowest rung earning the government determined basic 40 Rands a day and could then work their way through the ranks of semiskilled worker, skilled worker and supervisor to the top position of contractor earning 120 Rands a day, depending on their potential. Most of the participants - 12 of the 21 teams - and most of the funds - 16 million Rands were used to upgrade a full $250 \mathrm{~km}$ of footpaths to exacting standards. Two of the top teams should find future employment through long-term path maintenance contracts, while others may apply to train future beneficiaries and maintain the tented camps. Other, indirect small business opportunities were also created. For example, 49 tenders were awarded to service providers to transport the workers, while six kitchens were established to provide meals three times a week - effective training for budding entrepreneurs to establish bed-and breakfast establishments. The Department of Labour has helped set up a beneficiary data base where future job opportunities can be matched to the newly learned skills (ParkNews, 2008).

28 An additional benefit of this "social upliftment programme", according the IUCN Commission on Environmental Law (Mackey et al., $2008: 8$ ), is that it brings people from disadvantaged communities into contact with protected areas and their native ecosystems. This can begin to catalyse awareness through their community and help promote a greater appreciation of the values of and benefits from biodiversity conservation. So Green Card system and employment in the park are viewed as tools contributing to enhancing the enjoyment of the park and (re)connecting with nature and other population groups (Belaidi et al, 2018 ; Belaidi, 2016).

\section{Table Mountain National Park, a post-apartheid area}

The SANParks is now committed to promoting a different concept of conservation, one linked to issues of development and human needs. It is a concept that implies a harmonious relationship between people and parks and builds on traditional conceptions of wilderness and wildlife in African cultures. The key to this new concept 
of conservation is that it attempts to link the protection of biodiversity to human benefits ranging from employment of local people to their access to the sustainable utilization of resources of the parks. This shift could be described as the move away from a colonially inspired model of conservation focused on preservation to a more locally conceived model.

Traditionally, the logic of conservation in South Africa's national parks saw surrounding communities as inimical to biodiversity conservation. Neighbours were regarded as potential poachers and competitors for land and water, and their poverty was seen as an embarrassment from a touristic point of view. Park officials saw their relationship with neighbours as predominantly related to policing and maintaining fences between them. There was no notion of SANParks having any social responsibility towards its neighbouring communities. The SANParks authorities began in the mid-1990s to be sensitized to community issues, especially after having established a series of community forums. They saw the need to systematize community relations for what was called "social ecology" : a new conservation ethic which promotes a community-based development through conservation and tourism. The interactions between national parks and neighbouring communities have been formalized through forums (tribal authorities, youth leaders, educationalists, conservations bodies, village development committees, NGOs, governments departments), consultations with various stakeholders, public consultation. These tools are easing the way into public acceptance and a sense of common ownership of new conservation endeavours, in contrast with the former exclusive and exclusionary approach. (Cock and Fig, 2002 : $135,141,142)$

31 The promotion of natural (and cultural) heritage could contribute towards nation building and the creation of a common society in South Africa based on cultural sensitivity and awareness. This would involve reversing the ethnic particularism and notions of conservationism enshrined in apartheid. The significance of national parks is not limited simply to their capacity to preserve biodiversity and promote ecotourism (Cock and Fig, $2002:$ 148). In South Africa, they are fundamental in the promotion of empowerment strategies.

The role of popular participation in building awareness is manifest in the park management decision to poll opinion regarding the proposed change of name of the park to the Table Mountain National Park. The park was initially called the Cape Peninsula National Park due to the dominance of mostly white middle-class residents of the Peninsula on the old park committee and the side-lining (through distance) of the mostly black residents who lived on the far-flung Cape Flats. The poll voted in favour of the change and popularized the park citywide. Not a single citizen was in doubt as to where Table Mountain was and what it meant to them, yet only a select few knew where or what the Cape Peninsula was. The name of the park was thus formally changed to Table Mountain National Park in 2004 (Daitz and Myrdal, 2009 : 335).

In Cape Town, Table Mountain is the central landmark for each and everyone. Even before the city of Cape Town existed, the mountain exerted a power over the landscape. Known to the earliest occupants (KhoiSan) of the Cape as Hoerikwaggo, the mountain of the sea, and to the amaXhosa as Umlindi Wemingizimu, the watcher of the south, its presence created a landscape which was instantly recognizable. Early travellers from Europe were also struck by its singular outline and invented myths to tie it back into the familiar world they had left behind (Green, $2007: 189)^{12}$. It also functioned as a site 
of particular significance for the emerging white Cape middle class in the late $19^{\text {th }}$ and early $20^{\text {th }}$ centuries. It was conceived of as a space of natural beauty and botanical and spiritual significance (Van Sittert 2003). Then apartheid structured everyone's experience of living and working in the city before 1994, and its legacy in the physical organization of space is carried on. Ringed by group areas proclaimed white in 1957, Table Mountain provides a reference point for mapping the physical heritage of apartheid. The mountain has had a specific place in the apartheid city. The close relation people had enjoyed with the mountain when they lived in areas adjacent to it such as District Six (see for example Noor E., 1999) or Walmer Estate, before the forced removals in the early sixties, was defined as a space of relative freedom. While the mountain was a marginal space, it provided an opening in the otherwise closed system : a profound struggle at the level of everyday life to live with dignity. In this struggle, the mountain played a significant role against the way of life under apartheid.

Today, as the mountain has become a nexus in a web of economic and environmental activities which links it not only to the rest of the city but also to the rest of the world, it is more than ever perceived as inherent to the political and economic structures of the society which manages it. It has become the centre of complex negotiations between different users and interest groups, a resource within the international tourist economy to be managed efficiently and profitably. As TMNP advances nature conservation values, the City of Cape Town benefits from it, appearing as a "green" city, modern and ecologically responsible. The emphasis of these values allows to transform the image of a city known for its profound racial and social disparities, at the international and national level. Heritage and conservation strategies are thus used within "urban marketing" to serve a city project (Belaidi, 2012). Likewise, if the EPWP Project's official objectives aimed at alleviating poverty for disadvantaged communities surrounding the Park, it has projected an increase in the Park's revenue, through improved tourism infrastructure, in order to make it financially sustainable. It tries to develop the domestic tourism market in order to diversify revenue sources.

These examples of what SANParks called "benefits beyond boundaries" philosophy ${ }^{13}$ show that TMNP is a way to contribute to the economic development of the Cape Town Metropolis. The goal of the park is to deliver benefits to the city of Cape Town, the surrounding region and nationwide in terms of positive triple bottom line return on investment ${ }^{14}$. This demonstration of the value of conservation to the surrounding communities is what would secure the future of conservation. It could be argued that as long as national and local governments achieve real returns on investment and benefits in terms of poverty alleviation and improve tourism infrastructure, public sector investment opportunities can be justified and should be achieved. (Daitz and Myrdal, 2009 : 337)

The TMNP is at the same time a living space, a tourism market space and a protected space for its ecological qualities. These three functions are very different and are difficult to articulate in time, space and in the representations. SANParks made a choice : the social function of the TMNP is supporting the material benefit from which, this time, local communities should not be excluded. The transformation of the national parks from a colonial institution to a community-based conservation looks like a microcosm of the democratic movement. As SANParks reflects some of the hallmarks of the South African transition to democracy - negotiation, appeasement, inclusion, 
and reconciliation - it is part of the wider project of transforming South Africa into a just, democratic, and non-racial society.

The challenge in South Africa will be how to enhance a transformative vision for its national park that builds on the basis of environmental justice. In South Africa, the definition of this kind of justice focuses on aspects related to human and democratic rights (Mc Donald, 2002). Since it pays attention to how environment resources and their by-products are distributed and the inequitable power relations that lead to environmental injustices, it is - even implicitly - based on the idea that people should always be conscious that they are part of the natural world, inextricably tied to the ecological systems that sustain their lives. SANParks has committed itself to improving the lives of the majority of South Africans, through a wider access of the park for citizens to their mountain and the pride in and awareness of it as well as through the provision of economic opportunities to the communities bordering the parks (Daitz and Myrdal, 2009 : 337).

38 Simultaneously a natural enclave dedicated to conservation, a heritage site and an element of touristic sprawl around Cape Town and a tool for national reconciliation, the TMNP creates a very complex situation for stakeholders disputing multiple legitimacies based on different uses of ecosystems, resources or land, these many types of ecological appropriations imply different and potentially conflicting functions.

39 Therefore, gaining ecological appropriations tends to shape new spatial patterns. Creating a new national park, like Table Mountain National Park, thus make senses. The application of one of the oldest French legal theories - la destination de la chose - to this protected area has enabled us to determine the expanding strategy over a geographical area encompassing specific ecological values which in turn generate processes initiated by external parties to the considered space. The result of such a legal geography approach is that the protected area benefits from a specific social destination in a perspective of justice (for a discussion about environmental justice, Belaidi, 2015).

\section{BIBLIOGRAPHY}

Belaidi N., Soares Gonçalves R., Glei Maciel G., 2018, "Environmental education in urban national parks: political tool of democratization process. Experiences from Cape Town and Rio" in $\mathrm{F}$. Landy (dir.), From Urban National Parks to Natured Cities in the Global South - The Quest for Naturbanity, Springer Nature, coll. Environmental sociology, Singapore, pp. 265-283 Belaidi N., 2016, « Ecologie \& Réconciliation. Etude à partir des initiatives d'éducation à l'environnement sur Table Mountain National Park, Cape Town » in R. Porteilla et al., Afrique du Sud: 20 ans de démocratie contrastée, L'Harmattan, pp. 305-328.

Belaidi N., 2015, « Théorie du droit et front écologique : apport à la (re)définition de la justice environnementale ", Développement durable et territoires (en ligne), Vol.6, n¹, mis en ligne le 31 mars 2015, http://developpementdurable.revues.org/10806, 15 septembre 2016 
Belaidi N., Koubi G., 2015, « Droit et Géographie », Développement durable et territoires (en ligne), Vol.6, n¹, mis en ligne le 31 mars 2015, http://developpementdurable.revues.org/10798, 14 septembre 2016

Belaidi N., 2012, « Le Patrimoine mondial pour créer une identité commune dans l'Afrique du Sud post- apartheid ? Exemple de la ville du Cap » in Laurent Bourdeau, Maria Garavari-Barbas, Mike Robinson (dir.), Tourisme et patrimoine mondial, Presses de l'Université Laval, coll. Patrimoine en mouvement, pp. 269-284

Belaidi N., Berger M., Houssay-Holzschuch M., Ninot O., 2011, « Cape Town, périphéries postapartheid » in J.-L. Chaléard (dir.), « Les métropoles des Suds vues de leurs périphéries », Grafigéo, n³4, pp. 79-92

Birnie P., Boyle A, 2002, International law and the environment, Oxford, Oxford University Press, 888 p.

Blomley N., 1989, "Text and context: Rethinking the law-space nexus", Progress in Human Geography, n¹3, p. 512-534

Blomley N., 1994, Law, space and the geographies of power, New York, Guilford Press, 259 p.

Blomley N., Delaney D. and Ford R.T. (Eds), 2001, The legal geographies reader. Law, power, and space. Oxford, Blackwell Publishers, $356 \mathrm{p}$.

Boffa R., 2008, La destination de la chose, Paris, Defrénois,506 p.

Braverman I., 2011, "Hidden in Plain View: Legal Geography from a Visual Perspective", Law, Culture and the Humanities, vol.7, ${ }^{\circ} 2$, p. 173-186

Braverman I., Blomley N., Delaney D., Kedar A. (eds), 2014, The Expanding Spaces of Law: A Timely Legal Geography, Standford, Stanford University Press, 296 p.

Chaléard J.-L. (dir), 2014, Métropoles aux Suds, Le défi des périphéries ?, Karthala, Paris, 441 p.

Cock J. and Fig D., 2002, "From colonial to community-based conservation. Environmental justice and the transformation of national parks (1994-1998)" in Mc Donald D. A. (Ed), Environmental justice in South Africa. Athens, Ohio University Press, p. 131-155

Cowling R.M., Bond W.J., 1991, "How small can reserves be ? An empirical approach in Cape Fynbos”, Biological Conservation, n58, p. 243-256.

Cronon W., 1995, "The trouble with wilderness: or getting back to the wrong nature" in Cronon W. (Ed.) Uncommon Ground: Toward Reinventing Nature, New York, W.W. Norton, p. 69-90.

Daitz D. and Myrdal B., 2009, “Table Mountain National Park” in Suich H., Child B., Spenceley A. (Eds), Evolution and innovation in wildlife conservation. Parks and game ranchs to transfrontier conservation areas, London, IUCN-Earthscan, p. 325-339

Delaney D., 1993, "Geographies of Judgment: The Doctrine of Changed Conditions and the Geopolitics or Race", Annals of the Association of American Geographers, vol. 83, n¹, p. 48-65.

Dovers, S., Edgecombe R., Guest, B., 2002. South Africa's environmental history: cases and comparisons, Athens and Cape Town, Ohio university Press and David Philip Publishers, $326 \mathrm{p}$.

Ehrenfeld DW. 1976. The conservation of non-resources. American Scientist, n 64, pp. 648-656.

Fauvelle-Aymar F.-X., 2013, Histoire de l'Afrique du Sud, Seuil, Paris

Fuller S., 1999, Continuity and change in the cultural landscape of Table Mountain, MA thesis, Department of Environmental and Geographical Sciences, University of Cape Town 
Forest P., 2009, Géographie du droit. Épistémologie, développement et perspectives, Québec, Presses de l'Université de Laval, 286 p.

Goetze T., 2002, “Table Mountain - South Africa's natural national monument”, Historia, vol. 47, $n^{\circ} 2$, p. $457-478$

Government of the Republic of South Africa Department of Environmental Affairs and Tourism, 2003, Nomination of the Cape Floral Region of South Africa for inclusion on the World Heritage List, http://whc.unesco.org/uploads/nominations/1007rev.pdf, 15 septembre 2016

Green L., 2007, “Changing nature : working lives on Table Mountain, 1980-2000" in Field S., Meyer R., Swanson F. (eds). Imaging the city: memories and cultures in Cape Town. Cape Town, HSRC Press, p. 173-190

Griffiths T., Robin L., 1997, Ecology and Empire: environmental history of settlers societies, Pietermaritzburg, University of Natal Press, 248 p.

Guyot S., 2009, «Fronts écologiques et éco-conquérants : définitions et typologies. L'exemple des «ONG environnementales en quête de Côte Sauvage (Afrique du Sud) », Cybergeo : European Journal of Geography (en ligne), Environnement, Nature, Paysage, document 471, mis en ligne le 05 octobre 2009, http://www.cybergeo.eu/index22651.html, 9 septembre 2016

Hohl A., Tisdell A., 1994, "Conservation networks, integrated and sustainable land use in a tropical frontier - the Cape York Peninsula region, Australia", The Environmentalist, vol.14, $\mathrm{n}^{\circ}$ 4, p. 253-269

Holder J. \& Harrison C. (eds), 2003, Law and Geography, Oxford \& Toronto, Oxford University Press, $622 \mathrm{p}$.

Janzen DH. 1986. The future of tropical ecology. Annual Review of Ecology and Systematics, 17, pp. 305-324.

Joubert L., 2009, Invaded. The biological invasion of South Africa, Johannesburg, Wits University press, $265 \mathrm{p}$.

Kiss A. et Beurrier J.-P., 2000, Droit international de l'environnement, Paris, Pédone, 2 ème édition, 424 p.

Landy F. (dir.), 2018, From Urban National Parks to Natured Cities in the Global South - The Quest for Naturbanity, Springer Nature, coll. Environmental sociology, Singapore

London J. K., 1998, “Common roots and entangled limbs: Earth First! And the growth of postwilderness environmentalism on California's north coast", Antipode, vol. 30, n² 2, p. 155-176

Mackey B., Kintzele K., Aftandilian D., Engel R. and Heltne P., 2008, Keeping Nature Alive: Toward a Code of Ethics for Biodiversity Conservation, Biosphere Ethics Project Paper $n^{\circ}$. 2, IUCN, Gland, Switzerland in collaboration with the IUCN Environmental Law Centre, Bonn, Germany

Midgley G.F., Chapman R.A., Hewitson B., Johnston P., De Wit M., Ziervogel G., Mukheibir P., Van Niekerk L., Tadross M., Van Wilgen B.W., Kgope B, Morant P.D., Theron A., Scholes R.J. and Forsyth G.G., 2005, A status quo, vulnerability and adaptation assessment of the physical and socioeconomic effects of climate change in the Western Cape. Report to the Western Cape Government, Cape Town, South Africa. CSIR Report $n^{\circ}$ ENV-S-C 2005-073, Stellenbosch.

Noor E., 1999, Noor's story: My life in district six. Cape Town, District Six Museum, 88 p.

Norton BG, ed. 1986. The Preservation of Species: The Value of Biological Diversity. Princeton (NJ): Princeton University Press. 
Norton BG. 1987. Why Preserve Natural Variety? Princeton (NJ): Princeton University Press.

ParkNews-Table Mountain National Park, 2008

Porteilla R., 2010, L'Afrique du Sud. Le long chemin vers la démocratie, Infolio éditions, coll. Illico, Gollion

Rolston H III. 1994. Conserving Natural Value. New York: Columbia University Press.

Rosenzweig M., 2003, Win-win ecology: How Earth's Species Can Survive in the Midst of Human Enterprise, Oxford, University Press Oxford, $224 \mathrm{p}$.

SANParks and Settlement Planning Services - Land Use \& Environmental planners, 2001, Conservation Development Framework for the Cape Peninsula National Park, Report 1298/R3.3, https:// www.sanparks.org/parks/table_mountain/library/complete_cdf_mar01.pdf, 9 septembre 2016

SANParks, 2008, CDF Report - Conservation Development Framework 2006-2011 - Table Mountain National Park, Volume I et volume II, https://www.sanparks.org/docs/parks_table_mountain/ about/2008/CDF_vol1_report.pdf, https://www.sanparks.org/docs/parks_table_mountain/ about/2008/CDF_vol2_report.pdf, 9 septembre 2016

SANParks, 2016, Table Mountain National Park - Park Management Plan: 2015-2025, https:// www.sanparks.org/assets/docs/conservation/park_man/tmnp_approved_plan.pdf, 8 septembre 2016

SANParks, Alien Clearing, https://www.sanparks.org/parks/table_mountain/conservation/ clearing.php?p=Table\%20Mountain, 8 septembre 2016

Taylor W., 2006, The geography of law; landscape, identity and regulation,Oxford, Hart Publishing, 176 p.

Terreblanche S., 2005, A history of Inequality in South Africa 1652-2002, University of Natal Press, Pietermaritzbur

Thom B., 2004, "Geography, planning and the law: a coastal perspective", Australian Geographer, volume $35, \mathrm{n}^{\circ} 1$, p. 3-16

Thompson L., 2006, A History of South Africa, Jonathan Ball Publishers, Johannesburg \& Cape Town, 2006

Trinder-Smith T.H., Cowling R.M. \& Linder H.P., 1996a, "Profiling a besieged flora: endemic and threatened plants of the Cape Peninsula, South Africa", Biodiversity and Conservation, $\mathrm{n}^{\circ} 5, \mathrm{p}$. 531-574

Trinder-Smith T.H., Lombard A.T. \& Picker M.D., 1996b, "Reserve scenarios for the Cape Peninsula: High-, middle- and low-road options for conserving the remaining biodiversity", Biodiversity and Conservation, $n^{\circ} 5$, p. 649-670.

Turpie J.K., Heydenrych B.J. and Lamberth S.J., 2003, "Economic value of terrestrial and marine biodiversity in the Cape Floristic Region: implication for defining effective and socially optimal conservation strategies". Biological conservation, $\mathrm{n}^{\circ} 112$, p. 233-51

Urban Geography, 1990a,"Law, Regulation and Geography I", special issue, vol.11, n5

Urban Geography, 1990b, "Law, Regulation and Geography II", special issue, vol.11, n6

Van Sittert, L., 2003, “The bourgeois eye aloft : Table Mountain in the Anglo urban middle class imagination c1891-1952", Kronos, n² 29, p. 161-190.

Van Wilgen B.W., Richardson D.M., Le Maitre D.C., Marais C. and Magadleda D., 2001, “The economic consequences of alien plant invasions: examples of impacts and approaches to 
sustainable management in South Africa”, Environment, Development and Sustainability, vol. $3, \mathrm{n}^{\circ} 2$, p. $145-168$

Watson W., 2007, Brick by Brick. An informal guide to the history of South Africa, New Africa Books, Claremont, 2007

Wilson EO, ed. 1988. BioDiversity. Washington (DC): National Academy Press.

World Heritage Nomination - IUCN Technical Evaluation, 2004, The Cape Floral Region (South Africa) ID n': 1007 REV, http://whc.unesco.org/archive/advisory_body_evaluation/1007bis.pdf, 15 septembre 2016

\section{NOTES}

1. This study is part of 3 programmes : Front écologique et périurbanisation dans l'aire métropolitaine du Cap (Ecofront-CT), Axes « villes d'Afrique australe » et «transformations juridiques », Institut Français en Afrique du Sud 2009, coord. N. Belaidi (2009); Dynamiques territoriales à la périphérie des métropoles des Suds (PERISUD), ANR Les Suds 2007, coord. Jean-Louis Chaléard (2008-2011) ; Les parcs nationaux dans les mégapoles des pays émergents (UNPEC), ANR Blanc 2011, coord. F. Landy (2012-2016), cf Belaidi et al., 2011 ; Chaléard. 2014 ; Landy 2018.

In the framework of these programmes, I've more specifically studied the environmental governance as a specific object of research regarding the political and legal changes which are taking place in this geographic space. My research dealt with the analysis of the conditions of "valuation » of the Table Mountain National Park and the Kirstenbosch Botanical Garden in order to question the changes of shape and territorial as well as institutional organization (and the changes of contents and substance which they should carry on). I also dealt with their interactions with the social, ecological and political issues inherited from the apartheid and encompassed in the social and cultural stratifications. This allows to determine, based on the example, if and when environment is a lever of sustaining/creating a link between the increasing levels of economic welfare and the development of democratic regimes (emerging process), and between the changing social structures and the political competition. From a more global point of view, the research has proved that the massive investment of the environmental issue upsets the interstate framework within which the traditional global governance in this field used to be developed up to a recent date.

2. The Group Areas Act used to impose a strict residential segregation. It has been abolished in 1990, 4 years before the first democratic elections.

3. This reflection has been conducted within the framework of a collaborative research on the notion of eco-frontier, the purpose of which is to discuss and progress on the understanding, the theorization and application of this notion. It has been initiated with a workshop entitled: Territories and Networks of Eco-frontiers. International Experimental Workshop of "Eco-Political Geography", 27-30 May 2009, Université de Limoges, France.

4. Article 517 Code civil "Les biens sont immeubles, ou par leur nature, ou par leur destination, ou par l'objet auquel ils s'appliquent" ("property is immovable by its nature, by its intended use or by purpose, or by the object which it serves")

5. "Wilderness," according to the 1964 US Wilderness Act, is a place "where man himself is a visitor and does not remain." Another aspect of "wilderness" is that the wilder a place, the more natural it is. This concept has been exported to the rest of the world.

6. "Biological diversity" may be hard to define, but its intended meaning is not hard to understand : It refers to diversity at all levels of biological organization, from alleles, to populations, to species, to communities, to ecosystems. During the 1980s, biodiversity became the focus of concern of biologists alarmed by the increasing speed of anthropogenic extinction, 
particularly in the neotropics (Wilson 1988). Concern for biodiversity came to include the traditional focus on the potential extinction of charismatic (and culturally symbolic) species as well as those recognized as endangered by the 1973 Convention on International Trade in Endangered Species of Wild Fauna and Flora (CITES). "Biodiversity" includes allelic diversity within populations, structural differences between populations, diversity of species, and diversity at higher levels of ecosystems. In recent years, the targets of biodiversity conservation have expanded from the traditional concern with species and even ecosystems for including, for instance, consonance with cultural and religious traditions (Janzen 1986; Ehrenfeld 1976; Norton 1986, 1987; Rolston 1994).

7. It is a known fact that colonial segregation then Apartheid have, in South-African, been orchestrated via a territorial engineering both at the time of colonization and conquest. This enabled a limitation of the rights of african and coloured populations. Initially formalised by various processes from physical violence to market mechanisms such as access to work and education and including as well raising or lowering the value of given residential areas, the categories of racial classification have been used on a daily basis and became legal and compulsory as administrative and census categories. South Africa has only been a democratic country since 1996. Cf. Terreblanche, 2005 ; Thompson, 2006; Watson, 2007; Porteilla, 2010 ; Fauvelle-Aymar, 2013.

8. 1.7 times that of Southwestern Australia, 2.2 times that of California and the Mediterranean basin and 3.3 times the diversity of Chile. Only the islands of New Zealand, Hawaii and Madagascar have higher levels of endemism. The area has more plant species than the whole of the British Isles (with 1443 species in an area 600 times the size of the Peninsula) or New Zealand (with 1996 species in an area 530 times the size of the Peninsula).

9. Mike Slayen (Park conservation planning manager), ParkNews-Table Mountain National Park, Third Quarter, $2008: 7$

10. Act 57 of 1976, Section $2 B(1)(b)$

11. Proclaiming Table Mountain a national monument was part of the process creating a white national identity that symbolised a supposedly 'common' white colonial heritage (Goetze 2002). Before the forced removals of the 1950s, many Coloured families lived in the shadow of Table Mountain and fostered intimate relations with the urban mountains. cf Noor E., 1999

12. For instance, the myth of Adamastor invented by Luis de Camoens in the Lusiads identifies Table Mountain as an overthrown Titan, thus absorbing it into the familiar framework of Greek mythology.

13. "a new practice, getting people to understand why we need funding and measuring the impact that we're having. It's a more business-like approach, and our organisation has begun to realise that it must be done", Barry Stoffels (finance and administration manager), ParkNews-Table Mountain National Park, Third Quarter, 2008:8.

14. It had been proved that the Park made a positive economic contribution to the City of Cape Town by injecting 377 million Rand into the national Gross Domestic Product (GDP) between 1999 and 2003 from its operational and project expenditure alone (Standish et al. 2004).

\section{ABSTRACTS}

While legal geography is an emerging discipline, especially in North America, it is not yet a clearly defined field of research in France. In this article, we develop a conceptual framework 
based on a French legal theory applied to a protected area to show the convergence of perspectives between geography and law. Focused more specifically on how social values carried by law contribute to building space and place, this paper seeks to highlight a productive approach to the analysis of social relations.

Alors que la " géographie du droit » est une discipline émergente, en particulier en Amérique du Nord, elle n'est pas encore un domaine clairement défini de recherche en France. Dans cet article, nous développons un cadre conceptuel basé sur une théorie française du droit appliquée sur une aire protégée pour montrer les perspectives de convergence entre la géographie et le droit. Axé, plus précisément, sur la façon dont les valeurs sociales portées par le droit contribuent à construire l'espace et les lieux, cet article tend à mettre en relief une approche féconde pour l'analyse des relations sociales.

\section{INDEX}

Mots-clés: Géographie du droit, Théorie du droit, Aire protégée, relations sociales, nature/ fonctions

Keywords: Legal geography, theory of law, protected area, social relations, nature/functions

\section{AUTHOR}

\section{NADIA BELAIDI}

Chargée de recherche CNRSAnthropologie du droit/Droit international et comparé de l'environnementUMR 7206 Eco-Anthropologie

CNRS, Muséum National d'Histoire Naturelle, Sorbonne Université-Paris DiderotMusée de l'Homme, 17 place Trocadéro, 75116 Paris - nadia.belaidi@mnhn.fr 